\title{
Lung Transplantation: Advances and Roadblocks in Treatment
}

\author{
Matthew T. Hardison ${ }^{1}$ and J. Edwin Blalock ${ }^{2}$ \\ ${ }^{1}$ Medical Genetics Laboratories, Department of Human and Molecular Genetics, \\ Baylor College of Medicine \\ ${ }^{2}$ Pulmonary, Allergy and Critical Care Medicine, Department of Medicine, \\ University of Alabama at Birmingham \\ United States of America
}

\section{Introduction}

The increasing population age, along with the prevalence of smoking and other environmental factors have contributed to a dramatic increase in the incidence of chronic pulmonary diseases with no known cures. Chronic obstructive pulmonary disease (COPD), lung cancer, and primary pulmonary hypertension are all conditions with well understood origins but few, if any therapeutic options. When taken in conjunction with the prevalence of genetic or poorly understood conditions such as cystic fibrosis (CF) and idiopathic pulmonary fibrosis (IPF) there is a large and growing cohort of patients that will eventually enter end-stage lung disease. The only currently available treatment option is lung transplantation which may potentially be extremely beneficial in terms of quality of life and life expectancy, although carries with it a vast array of considerations and complications. This chapter attempts to provide an account of the progress made in lung transplantation, complications associated with the procedure, current treatment for transplant associated conditions, and finally will discuss current research and possible future therapeutics.

\section{History of lung transplantation}

Lung transplantation remains the final therapeutic option for treatment of patients with diverse diagnoses of end stage lung disease. (Arcasoy and Kotloff 1999) This however, has not always been the case. It was only within the last three decades that the medical community achieved reproducible outcomes that translated into clinical improvement in the condition of the patient. Vladimir Demikhov is considered by some to be the founder of the field due to his work in animal models in the mid 20th century, but it wasn't until 1963 that the first attempt at human lung transplantation occurred. (Cooper 1969; Hardy et al. 1963) This early trial was in a prisoner with both terminal lung cancer, and severe emphysema. Unfortunately, the patient died a mere 18 days post-transplantation. (Cooper 1969) It was almost another two decades before the first successful heart-lung transplantation was performed resulting in the multi-year survival of the recipient. This 1981 triumph was followed up by a group out of Toronto that proved once and for all that the one-time pipe dream of regular lung transplantation in humans was, in fact, a reality. (Cooper et al. 1987) 
It was in the early 1990s that a comparative "transplant boom" began and has since leveled off to the approximately 2,700/year lung transplants performed worldwide today. (Orens and Garrity 2009) The relatively limited number (compared to other whole organ transplant procedures) of lung transplantations is a factor of limited supply of acceptable organs and ability to procure donor tissue. (Dilling and Glanville 2011) Unfortunately, it is because of this dearth of patients that few multi-center trials have been performed to assist in the investigation of better pre-, peri-, and post-operative techniques. However, with the increase in surgeries seen in the 1990s, serious efforts at reducing the risk factors associated with lung transplantation were initiated.

\section{Selection of candidates}

The majority of this chapter will deal with the complications and efforts to reduce them post-transplantation, but we will briefly touch on steps that have been implemented to reduce risk exposure prior to surgery. These preventative steps begin with a strict limitation on those who are eligible for transplant. Typically, individuals 55 and older are considered unsuitable for operation; although the mean age of recipients has been steadily increasing (it is currently over 50). (Dilling and Glanville 2011) Multiple organ failure, history of noncompliance, active/recent cigarette smoking, and active cancer are all contraindications for enrolling a patient in the United Network for Organ Sharing (UNOS). (Maurer et al. 1998) One of the most important factors that clinicians must consider when evaluating a patient for transplantation is the infection state of the possible recipient. While most bacterial and/or viral colonizations are permissible, there are many transplant centers that refuse to operate on patients with unremitting infection with pan-resistant $P$. aeruginosa and B. cepacia. Even so, there is at least one group out of Canada that is willing to consider transplantation of this patient population. (Nash et al. 2010; Flume et al. 1994) Prior to 2005, the allocation of lungs in the United States was dependant solely on waiting time; those who had been on the list longer were given priority over newly enrolled patients. Unfortunately, this obviously created a selection bias against the acutely ill. In 2005 the Lung Allocation System underwent an overhaul, utilizing a Lung Allocation Score (LAS) to determine those patients that were both most in need of transplantation, and most likely to survive the surgery and excel in recovery. (Egan et al. 2006) The new LAS system includes a number of factors (age, 6 minute walk test, forced vital capacity (FVC), body mass index (BMI), etc) to determine the patient's predicted waitlist survival time. The LAS is equal to (Calculated 1 year survival benefit) - (Calculated 1 year waiting list survival). (Morton and Glanville 2009) Obviously, there are limitations to this type of allocation system; certain subjective metrics like functional status and diagnosis can affect the patient's LAS, but the new method of lung allocation appears to have had a beneficial effect on median survival time posttransplantation.

\section{Selection of donor organs}

\subsection{Blood group matching and CMV status}

All of the evaluations discussed above are recipient-focused mechanisms designed to facilitate better outcomes in lung transplantation, but perhaps some of the most important protocols in place are related to obtaining the most viable donor organ available. There are several factors that contribute to the difficulty of procuring optimal lungs. Due to the 
extremely limited time that lungs are able to endure ischemia (less than 6 hours), there is little opportunity to perform traditional human leukocyte antigen (HLA) matching. Physicians face an unfortunate catch-22; better HLA matching reduces incidence of chronic rejection, but increased ischemic time in turn leads to a higher propensity for rejection. (Brugiere et al. 2008) Blood groups, rather, are the primary method of histological matching, with consideration being given to size and cytomegalovirus (CMV) sero-status. However, this is somewhat disputed in a review of the heart-lung transplant patient population at Stanford. (Deuse et al. 2010) CMV sero-negative recipients are at a higher risk of developing CMV infection when miss-matched with sero-positive donors than those recipients that are already CMV sero-positive. CMV infection has shown to be immunomodulative; creating an increased risk of acute and chronic rejection, and infections. (Freeman 2009) Like other opportunistic infections, there is an increased risk of CMV disease with the use of immunosuppressive treatment, although CMV in turn increases the risk of rejection, defeating the intent of the immunosuppressive therapies. (Fishman et al. 2007) CMV infection is not only limited to lung transplant recipients and thus there have been significant efforts from all corners to establish a gold-standard of prevention and treatment for CMV disease in all transplant patients. In studies performed in kidney and liver recipients, investigators demonstrated a significant reduction in incidence of CMV disease and viremia, along with significant reduction in the number of opportunistic infections in patients treated with prophylactic valganciclovir. (Humar et al. 2010) Valganciclovir is currently considered the gold-standard in CMV prevention, but other DNA polymerase inhibitors, including ganciclovir and valacyclovir have been in use for several years with a smaller impact. (Zamora et al. 2004) Unfortunately, lung transplant recipients face a higher incidence of CMV infection than any other transplant patient population. This is for two primary reasons; first, CMV dormancy and recurrence have been shown to be higher in the lungs than anywhere else, and, unlike other whole organ transplant surgeries, there is a preponderance of lymphatic tissue transplanted with the lungs that contains further amounts of dormant virus. (Zamora, Davis, and Leonard 2005)

\subsection{Other donor factors}

Although blood group matching and CMV sero-status are two of the most important criteria when evaluating potential donor lungs, there are a multiple other factors surgeons must consider when assessing a possible donor organ. Traditionally it has been protocol to decline any lungs from donors positive for hepatitis B, even so, recent work has cracked open the door to this pool of donors, potentially increasing the donor pool and number of available organs. A 1-year longitudinal study showed no significant difference in survival of hepatitis B positive donor lung recipients compared to the hepatitis B sero-negative group. (Dhillon et al. 2009) The physicians must also take into account something as simple as time and distance when determining the possibility of performing the potentially life-altering operation. Lungs, like any other tissue, are susceptible to ischemia-reperfusion (IR) injury and the flood of damaging cytokines that go along with it. Primary graft dysfunction, which can occur in up to $20 \%$ of patients, has been directly attributed to IR injury. (Christie, Sager et al. 2005) In addition to this, the lungs are more readily affected by the abundance of fluids that are typically given in end of life situations. (Arcasoy and Kotloff 1999) Current thinking is that non-heart beating donors (NHBD) are ill suited for the harvesting of lungs due to the perceived damage that warm extended periods of ischemia would incur. This has been challenged, however by a group in Canada demonstrating no ill-adverse effects from the use 
of this here-to-for off-limits pool of potential donor candidates. They state that there is an ameliorative effect on the levels of inflammatory cytokines present in these lungs which off sets the perceived ischemic damage. (Cypel et al. 2009)

Donor age is another consideration that is factored in when considering possible transplantation. Not surprisingly, elevated donor age and increased ischemic times correlate with worse outcomes in transplant recipients. (Meyers and Patterson 2000) While not optimal, there is such a shortage of available donors, NHBDs over the age of 60 now represent over $10 \%$ of the NHBD donor population. (Ojo et al. 1999) There are several techniques available to try and optimize the donor lung, but most common are the use of vasopressin, and thyroid hormone. (Botha et al. 2008) Finally, brain dead (BD) donors represent a potential donor pool that presents its own unique set of possible complications. In animal models of $\mathrm{BD}$, investigators observed a three fold increase in the blood volume in the pulmonary circulation within minutes after onset of BD. (Avlonitis et al. 2005) This, in concert with loss of sympathetic tone, contributes heavily to a rapid onset of pulmonary edema which in and of itself is enough to dissuade many surgeons from considering using the tissue. Furthermore, several groups have reported a significant increase in the concentrations of pro-inflammatory cytokines such as interleukin-1 (IL-1), IL-2, IL-6, and tumor necrosis factor-alpha (TNFa). (Skrabal et al. 2005; Pratschke et al. 2000; Shohami et al. 1994) Additionally, the neutrophil chemokine, IL-8, has also been demonstrated to be elevated in the lungs of BD lung donors. (Fisher et al. 1999) Increased neutrophil burden has been strongly associated with increased matrix-metalloprotease activity and possible exposure of the autoantigen collagen V (Coll V). (Fisher et al. 2001; Hardison 2009) The exposure of Coll V directly correlates with the incidence of primary graft dysfunction. (Iwata et al. 2008)

All of the considerations discussed contribute to the limited number of lung transplants that are performed each year, but the lack of family consent is by far the largest obstacle to available donor organs. (Spital 2005) Since it is unlikely that an automatic-enrollment system similar to other countries is likely, it is vital that the best efforts are made to elucidate the mechanisms behind the numerous and varied complications inherent in lung transplantation by both basic scientists and clinicians alike. The litany of assessments and interventions discussed thus far are all employed to attempt to prevent the plethora of posttransplantation complications that can arise. The unfortunate reality is that while surgical techniques and medical therapeutics are far more advanced and elegant than when the initial forays in lung transplantation occurred, there is still ample room for improving the outcomes observed in lung transplant recipients. The remainder of this chapter will discuss post-transplantation complications, current therapies, recent research in the field, and the exciting possibilities for novel therapeutics that are on the horizon.

\section{Post transplantation complications}

Due to the myriad of risk factors associated with lung transplantation, it has one of the highest morbidity and mortality rates of any whole organ transplant procedure. (Trulock et al. 2007) Only recently has the mean survival time for transplant recipients risen to 5.7 years. (Ahmad, Shlobin, and Nathan 2011) There are four major causes of morbidity and mortality in all transplant recipients; primary allograft dysfunction, infection, acute rejection, and chronic rejection. These four primary causes are closely related; rather they exist on a spectrum with the incidence of chronic rejection (the most serious) rising with increasing occurrences of the PGD, infection and acute rejection. 


\subsection{Primary graft dysfunction \\ 5.1.1 Characterization and etiology}

Primary graft dysfunction (PGD) is defined as having a $\mathrm{PaO}_{2} / \mathbf{F i} \mathrm{O}_{2}$ of $\leq \sim 300$ with radiographic infiltrates consistent with pulmonary edema. (Christie, Carby et al. 2005) PGD is further categorized into 3 gradations with Grades 1, 2 and 3 corresponding to $\mathrm{PaO}_{2} / \mathbf{F i ~ O}$ greater than 300, between 200 and 300, and less than 200, respectively. Clinically, PGD is simply a unique form of acute lung injury (ALI), presenting within 72 hours post-surgery with replete pulmonary infiltrates/edema and impaired compliance. These guidelines for evaluating PGD were initially put forth in 2005 by the International Society for Heart and Lung Transplantation (ISHLT) Working Group on PGD and later confirmed by a retrospective study of approximately 400 lung transplant recipients. This study demonstrated that PGD grade 3 did indeed correlate with the worst mortality. (Prekker et al. 2006) PGD can affect up to $25 \%$ of patients and correlates with much higher levels of mortality in the first 30 days. (Christie et al. 2005) The precise cause(s) of PGD are still unknown, but it is widely accepted that ischemia-reperfusion (IR) injury plays a major role in initiating the destructive process. It is in the ischemic period that reactive oxygen species (ROS) are produced in large quantities and directly damage the pulmonary epithelium and endothelium. (Tasoulis et al. 2009; de Perrot et al. 2003) This influx of ROS incites a proinflammatory cascade that activates both the innate and complement immune systems. (Carter, Gelman, and Kreisel 2008)

\subsubsection{Risk factors for PGD}

Advanced age of organ donors is strongly associated with increased incidence of PGD in lung transplant recipients. What is interesting is that no definitive studies have been performed that indicate that recipients' age play any role in the development of PGD. (Barr et al. 2005; Christie et al. 2003) Additionally, race (African-American), sex (female), and smoking history are all donor-dependent risk factors in the development of PGD. (Lee and Christie 2009) No conclusive studies of transplant recipients have explicitly delineated whether indication for transplantation correlates with development but it appears that idiopathic pulmonary fibrosis confers at least some increased risk of PGD. (Barr et al. 2005) Pulmonary arterial hypertension (PAH) has emerged as the only clinically measureable metric that correlates with the development of primary graft dysfunction. While the precise pathway of PAH to PGD is as yet unknown, multiple studies have demonstrated the relationship. (Whitson et al. 2006)

\subsubsection{Treatment of PGD}

Although over-used to the point of being a cliché, the maxim "an ounce of prevention is worth a pound of cure" is distinctly applicable to the treatment of primary graft dysfunction. Increasing emphasis is being placed on improved preservation of the donor organ. The main weapon in the clinician's arsenal of preservative techniques is induced hypothermia of the tissue. It has been demonstrated that by maintaining the organ at $4{ }^{\circ} \mathrm{C}$, the metabolic rate is drastically reduced compared to that of control temperature tissue. (de Perrot et al. 2005) Two methods of organ cooling are typically employed; core cooling and pulmonary arterial flush (PAF). (Okada and Kondo 2009) The core cooling method occurs prior to organ explantation and is initiated with cardio-pulmonary bypass to reduce the body temperature to $\sim 14^{\circ} \mathrm{C}$. Upon harvesting, the donor lungs are submerged in $4^{\circ} \mathrm{C}$ saline. 
PAF is accomplished by instilling $60 \mathrm{ml} / \mathrm{kg}$ into the pulmonary artery, there have been some recent studies investigating the effects of a dual flush with the addition of flushing the pulmonary veins as well. The hypothesis being that this would ensure the complete removal of micro-thrombi in the capillaries and result in a more equitable distribution of the preservative solution. (Struber et al. 2002) There are several different "recipes" of preservative solution but the first in wide use (Euro-Collins solution), with high a high $\mathrm{K}^{+}$ and low $\mathrm{Na}^{+}$concentrations to mimic intracellular fluid, was originally developed for use in liver preservation. (Okada and Kondo 2009) Since then, more sophisticated preservation solutions have been developed and are in the process of being tested. The Okada group developed a solution termed extra-cellular phosphate buffered saline type 4 (Ep4) that included dextran 40. This solution was capable of preserving canine lungs for up to $96 \mathrm{hrs}$ post-explantation. Dextran 40 appeared to exert an anti-coagulative effect, ostensibly by forming a protective coat on the endothelial surface. (Handa et al. 1989; Okada et al. 1997; Colombat et al. 2004)

Sadly, if efforts to prevent the development of primary graft dysfunction fail, the similarity to acute lung injury (ALI) and acute respiratory distress syndrome (ARDS) results in little that the clinician can do other than provide supportive care. Due to the increased concentration of pro-inflammatory cytokines in the pulmonary circulation it is of vital importance that fluid administration is closely monitored to decrease the risk of fulminant edema. (Shargall et al. 2005) In addition to the vigilance given to the administration of fluids in PGD patients, ventilator settings can play a major role in outcomes of those individuals. A multicenter, randomized, controlled trial demonstrated that lower tidal volumes, combined with elevated positive end expiratory pressure (PEEP) were significantly protective in individuals with ARDS. The authors of the study hypothesize that this was due to the decreased alveolar damage in the hyper-compliant lungs. (Petrucci and Iacovelli 2003)

\subsubsection{Current research and future directions}

Much of the current research in this area is focused on the development of better therapeutics and the identification of biomarkers in PGD to provide a deeper knowledge of the genetic and biochemical forces that are integral in the genesis of the condition. With the recent advances made in high through-put proteomics and DNA micro-array technology there are ample platforms to rapidly pursue numerous avenues of investigation in great detail.

\subsubsection{Potential Biomarkers of PGD}

A 2006 study by Kaneda et al, utilizing quantitative real time polymerase chain reaction (qPCR) revealed that the IL-6/IL-10 ratio in the donor lung was predictive of 30 day mortality in the transplant recipient. (Kaneda et al. 2006) Luminex analysis of blood samples from 25 Grade 3 PGD patients and 25 Grade 0 control patients by Hoffman, et al revealed a vastly different chemokine profile in the two population's plasma. Severe PGD patients had significantly elevated levels of monocyte chemotactic protein-1 (MCP1) and CXC motif ligand 10 (CXCL10) compared to controls. (Hoffman et al. 2009) The detection of novel biomarkers is not limited to new sophisticated techniques, more traditional approaches also have also yielded results. Indeed, a recent study by Diamond, et al, using a conventional "sandwich" enzyme linked immunosorbent assay (ELISA) provided evidence that increased Clara cell secretory protein 16 (CC16) was significantly associated with the development of PGD. (Diamond et al. 2011) There are numerous other studies that have produced a litany of 
possible biomarkers (soluble receptor for advanced glycosylation end-products (sRAGE), soluble P-selectin, Protein $C$, etc.) for primary graft dysfunction and that may one day provide the key to its early detection and prevention. (Kawut et al. 2009; Christie et al. 2007; Christie et al. 2009)

\subsubsection{Novel/Future Therapeutics for PGD}

The goal of those developing novel therapeutics for PGD is the prevention of the condition itself. A multi-center, randomized, placebo controlled trial by Keshavjee, et al showed a protective effect in the use of soluble complement receptor-1 (sCR1) resulting in decreased time to extubation and a trend toward abbreviated intensive care unit (ICU) stays. (Keshavjee et al. 2005) In an intriguing study by Eriksson, and colleagues, induced hypothermia appeared to be beneficial in case studies of PGD patients and was recapitulated in an animal model. (Eriksson and Steen 1998; Eriksson et al. 1999) Significant forays into the use of inhaled Nitric Oxide (iNO) as a therapeutic agent have also been made in recent years. There have been discordant results, however as to the efficacy, ranging from no change in outcomes to a decreased incidence of severe PGD and diminished concentrations of IL-6 and IL-8 in plasma compared to controls. (Meade et al. 2003; Ardehali et al. 2001) Due to the prevalence of PGD in lung transplant recipients, and the comparative lack of knowledge regarding the pathogenesis of this condition, it is reasonable to expect considerable resources to continue to be directed toward the investigation and prevention of this syndrome.

\subsection{Infection}

\subsubsection{Characterization and etiology}

Infection in post lung transplantation begins as any other infection, however with the host being in the unenviable position of possessing immune systems under active and permanent suppression, in addition to the mechanical and physiologic stress that is inherent to any major surgery. Infection is, in fact, the primary source of mortality in the first year posttransplant and continues to be a significant source of morbidity and mortality for the remainder of the recipient's life. (Corris and Christie 2008) Unlike all other solid organ transplants, the lungs are open to the external environment and all of the pathogens, both virulent and opportunistic, that entails. Furthermore, the denervation that is a necessary component of organ harvesting results in at least a temporary impairment in the cough reflex and thus diminished clearance. (Ahmad, Shlobin, and Nathan 2011) It is important to note that any infection, particularly recurrent infection, is a risk factor for the occurrence of rejection, both acute and chronic. Rapid identification of the pathogen and appropriate treatment is optimal to decrease morbidity and mortality in this patient population.

\subsubsection{Bacterial infection}

Bacterial infections are the most common type of infection in lung transplant recipients and occur in a bi-modal, temporal-dependant manner. Pulmonary bacterial infections are common both early, due to the previously mentioned impaired cough reflex and damaged lymphatic system, and late, as an element of chronic rejection. (Kramer et al. 1993) Due to the nature of the pre-transplant disease, those patients with cystic fibrosis (CF) are the most difficult to maintain in an infection free state. This is especially true in the individual with a single lung transplant due to the potential for colonization from the native lung. Interestingly, the CF patient population also has the best long-term results despite the proclivity towards infection. (Lease and Zaas 2010) 
Pseudomonas aeruginosa is the most common bacterial organism isolated from the posttransplant lung. (Kramer et al. 1993) This opportunistic infection has a higher incidence in CF patients and has been estimated to be responsible for up to $33 \%$ of pneumonias in all transplant recipients. (Aguilar-Guisado et al. 2007; Campos et al. 2008) P. aeruginosa airway infection prior to transplant does not appear to demonstrate a predictive relationship for chronic rejection. However, this is not the case for colonization in the post-operative period. (Botha et al. 2008; Vos et al. 2008) P. aeruginosa infection is not limited to pneumonias; the pathogen has been reported to be responsible for nearly half of all post-transplant infections. (Valentine et al. 2008)

Mycobacterium is a designation indicating acid-fast bacteria that are capable of causing a wide range of diseases. Perhaps the most well known of these M. tuberculosis, has the robust cell wall that is a calling card of the classification, and helps to confer resistance to broad spectrum antibiotics. Although, not nearly as common as $P$. aeruginosa infection, $M$. tuberculosis colonization presents a unique set of treatment hurdles, especially in the presence of multi-drug resistant (MDR) strains. (Lee et al. 2003)

Opportunistic infections, hospital-acquired infections, and resistant strains of bacteria are all significantly more common in lung transplant recipients than the general population. Staphylococci strains have demonstrated a propensity for antibiotic resistance and this is only magnified in the already immunosuppressed transplant patient. Specifically, S. aureus is the second most common organism isolated from the airway, with multi-drug resistant $S$. aureus (MRSA) being extremely difficult to treat due to its almost pan-resistant nature. (Kotloff and Thabut 2011)

\subsubsection{Treatment of bacterial infection}

The treatment of infection in lung transplant recipients is a challenging task due to the patients' significant cocktail of immunosuppressive therapies. Many of these drugs, including cyclosporine and tacrolimus can be highly cross-reactive. There is unfortunately no "magic bullet" specific for transplant patients, the traditional regimen of broad spectrum antibiotics, with specific coverage for gram negative, acid-fast, etc. being added upon differential diagnosis.

\subsubsection{Fungal infection}

While colonization by widespread fungi such as Aspergillus and Candida is common, a much smaller percentage of patients will develop a clinically relevant fungal infection. (Singh 2003) Aspergillus and Candida are by far the most common, with Cryptococcus species and other molds playing a much smaller role. (Neofytos et al. 2010) The presence of foreign material (sutures) in the airway anastomosis, in addition to the inherent risk with ventilation, increases the risk of fungal infection in post-operative transplant patients.

\subsubsection{Prevention/treatment of fungal infection}

Similar to the treatment of bacterial infections, the therapeutic approach to fungal infection in lung transplant patients is primarily unchanged from the normal treatment options in other patients. Treatment regimens will typically consist of aerosolized Amphotericin B in the acute post-operative period, with voriconazole and itraconazole prophylactic treatment extending for up to a year post-transplantation. (Ahmad, Shlobin, and Nathan 2011) 


\subsubsection{Viral infection}

As has previously been mentioned, the sero-status of cytomegalovirus (CMV) is an important factor in opting to transplant or harvest donor organs. CMV is by far the most common viral pathogen observed after lung transplant procedures, affecting at least a third of all patients. CMV usually presents with fever, exhaustion, and flu-like symptoms with associated leukopenia. (Snydman et al. 2011) Diagnosis of CMV syndrome is made with PCR evaluation of viral titers in peripheral blood. If CMV pneumonia is suspected, the definitive test must be performed on a biopsy specimen of the in tissue. (Kotton et al. 2010) CMV infection has been shown to predispose the patient to infection with other community acquired respiratory viruses (CARVs). (Sims and Blumberg 2011)

In a recent three year longitudinal study, Kumar et al showed the presence of virulent strains of H1N1 influenza, adenovirus, flu A, flu B, and rhinovirus in over half of transplant recipients. (Kumar et al. 2010) Diagnosis of these viral infections has become much more straightforward with the advent of qPCR to provide rapid evaluation of viral titer loads in bronchoalveolar lavage (BAL) fluid of patients. Antibody based assays are also available to determine the infection state of an individual, although these may vary from center to center.

\subsubsection{Prevention/treatment of viral infection}

Intravenous (IV) ganciclovir and the oral pro-drug valganciclovir are given prophylactically for anywhere from 6 to 12 months post-transplant. (Jaksch et al. 2009) CMV prophylaxis is standard protocol for all patients regardless of center and has been shown to be effective in reducing the CMV syndrome. (Palmer et al. 2010) Treatment for CARVs is dependant upon specific diagnosis of pathogen and strain and can include zanamivir, amantidine, oseltamivir, etc. (Ison and Michaels 2009) Unlike CMV therapy, prolonged treatment with these anti-virals is contraindicated for fear of contributing to the development of resistance.

\subsection{Acute rejection}

\subsubsection{Characterization/etiology of acute rejection}

Acute rejection (AR) presents clinically with non-specific symptoms including dyspnea, mild fever, malaise, cough, and leukocytosis. Although not present in all AR exacerbations, radiographic imaging may show mild pleural effusion, and interstitial opacities with a concurrent decline in oxygenation and spirometric measurements. (Millet et al. 1989; Otulana et al. 1990) AR is definitively diagnosed by BAL and TBB followed by histological analysis showing perivascular infiltrates. (Stewart et al. 2007) TBB may not always be possible due to patient status and thus AR is tentatively determined based upon clinical symptoms and radiologic evidence. Many transplant centers have post-transplant protocols that include routine monitoring by BAL which is also capable of confirming AR. (Chakinala et al. 2004) Most importantly, as indicated by the name, acute rejection is just that, a brief intermittent condition that is most often easily resolved with or without hospitalization.

Acute rejection is an extremely common complication of lung transplant patients, occurring in as many as $90 \%$ of lung recipients over their lifespan. (Arcasoy 2004) The incidence of AR is highest within the first year post-transplant, afflicting approximately one third of all patients. (Christie et al.) It is difficult to determine precise results in these retrospective studies due to the fact that AR can be clinically silent, only detectable upon transbronchiole biopsy (TBB). (Hopkins et al. 2002) The precise etiology of AR is still unknown but stratified risk appears to be heavily weighted toward donor-dependent factors in the immediate post- 
operative period, with recipient-dependent factors playing the predominant role after the first year. HLA-B mismatching, increasing donor age, non-O donor blood type, and increasing body-surface area (most likely corresponding to elevated BMI) all correspond with increased AR incidence. With a recipient history of diabetes, and recent transplant accounting for recipient driven risk in the intermediate and late phase AR. (Mangi et al. 2011)

The International Society for Heart-Lung Transplantation (ISHLT) has delineated the standard nomenclature to describe the various gradations of AR based solely on histological findings. Grade A0 is the absence of AR, no cellular infiltrates and healthy lung parenchyma. Grade A1 is characterized by patchy mononuclear cell infiltrates in alveolar parenchyma. Grade A2 is described as having more prevalent lymphocytic infiltrates centered in the perivascular area with the presence of some activated macrophages and eosinophils. Grade A3 features dense perivascular infiltrates, significant eosinophil presence, with the first observation of neutrophils in the intra-alveolar space. Grade A4 describes the finding of diffuse mononuclear infiltrates, pneumocyte damage, macrophage and neutrophil presence. (Stewart et al. 2007)

\subsubsection{Treatment of acute rejection}

Similar to many aspects of lung transplantation, treatment for AR varies dependant upon hospital setting with some centers opting to not treat AR considered to be <Grade A2. (Orens and Garrity 2009) In more severe cases however, conventional treatment consists of a hospital admission with a three day course of solumedrol followed by an oral prednisone taper. (Aboyoun et al. 2001; Yousem et al. 1994) Additional treatment with methotrexate, lymphoid irradiation, and antithymocyte globulin, among others, has been reported to be effective in alleviating the transient AR condition. (Hachem 2009)

\subsubsection{Biomarkers of acute rejection}

Although ISHLT has defined acute rejection based solely upon histological findings, there is significant effort to describe biomarkers specific to patients undergoing AR to better classify and determine treatment. A recent study by a group out of Copenhagen described elevated mRNA of the regulatory T cell (Treg) cytokine FoxP3, along with cytotoxic T cell-derived granzyme B in BAL fluid of patients in AR. (Madsen et al. 2010) A 2007 study by Lande et al describes the use of microarray analysis to observe relative gene expression levels of cytokines thought in be involved in acute rejection in the BAL fluid of AR patients. (Lande et al. 2007)

\subsubsection{Novel/future therapeutics of acute rejection}

Due to the incredible amounts of data generated by high through methods such as massspectrometry-assisted proteomics and gene microarray analysis there have never been more targets identified for the design of targeted therapeutics in acute rejection. The use of animal models of acute rejection have also significantly improved the ability to design and test novel therapeutics for acute rejection allograft rejection in lung transplantation.

Jung et al (2006) have developed a spontaneous model of acute rejection in rats by performing lung transplantation in a manner similar to that used in humans. By utilizing a small molecule, irreversible inhibitor of dipeptidylpeptidase IV (DPPIV/CD26) the investigators reduced the incidence of acute rejection, preserved lung function, and 
maintained normal histological structure in rat lung transplantees. (Jung et al. 2006) They previously published that DPPIV/CD26 was elevated in plasma of rats undergoing AR after cardiac transplant and hypothesize that the pulmonary protective effect is due to reducing the co-stimulatory effect of DPPIV/CD26 on T cells. (Korom et al. 1997) In a similar model, a group out of Fukouka, Japan employed a Janus kinase 3 (Jak3) inhibitor to prevent the development of AR. Jak3 is located at a biochemical bottleneck in the pathway of T cell clonal expansion. Higuchi, et al demonstrated a dose-dependant inhibition of the development of acute rejection by the AG490 in the experimental population. (Higuchi et al. 2005)

Animal models are not the only avenue available to scientists to pursue better methods of treating and preventing acute rejection. Investigators at the University Clinics of Leipzig reported a reduction in the incidence of acute rejection with preemptive administration of the traditional therapeutic methylprednisone. By simply giving bolus doses 2 hours prior to incision and immediately prior to completion of the transplant procedure they observed a significant improvement in outcomes. (Bittner et al. 2010)

Clearly this is not meant to be an exhaustive review of the potential novel therapeutics currently under development. We are merely presenting a representative sample indicating the myriad of pathways that are being studied to yield targeted countermeasures to acute rejection.

\subsection{Chronic rejection (bronchiolitis obliterans syndrome)}

\subsubsection{Characterization/etiology of bronchiolitis obliterans syndrome}

Chronic rejection, clinically termed bronchiolitis obliterans syndrome (BOS), is the primary source of morbidity and mortality seen in the lung transplant patient population. (Bando et al. 1995; Stewart et al. 2007) Due to the nature of BOS, primarily occurring irregularly in the small airways, diagnosis by transbronchial biopsy is ineffective. (Chamberlain et al. 1994) Diagnosis of BOS is difficult due to its similarities with other post-transplant complications. There are no tests to specifically determine BOS, rather, it is a diagnosis of exclusion. A persistent, unexplainable drop in forced expiratory volume in one second (FEV1) ( 80\% of baseline) with accompanying decline in FEV25-75 (less than or equal to 75\% of baseline) is defined as BOS stage 0. (Belperio et al. 2009; Estenne et al. 2002) BOS is staged 0-3 based upon progressive declines in percent of expected FEV1.

BOS is unfortunately observed in over half of lung transplant patients who survive five years or more post-transplantation. (Bando et al. 1995) Chronic rejection initially presents clinically in a manner similar to that of other complications with dyspnea, cough, and progressive airway obstruction. (Estenne and Hertz 2002) X-ray analysis is often unremarkable, but computer assisted tomography (CT) may reveal air trapping and bronchiectasis. (Morrish et al. 1991)

BOS is characterized pathologically by a prominent neutrophilic component with a definite increase in pulmonary fibrosis and extra-cellular remodeling. (Billings et al. 2002; Boehler and Estenne 2003) The BAL fluid of the majority of BOS patients reveals chronic pulmonary neutrophilia. Indeed, when $>20 \%$ of cells are neutrophils in BAL fluid patients fail to survive past 7 years post-transplant. (Neurohr et al. 2009) Unlike acute rejection, where the cellular infiltrates are centered around the vasculature, in BOS, the cells are located primarily in and around the airways with a striking increase in cell number and activation level of leukocytes. (Vanaudenaerde et al. 2008) The causes of BOS are only partially understood with much unknown about the exact causative events that lead to disease. 


\subsubsection{Risk Factors for bronchiolitis obliterans syndrome}

What facts are known about the pathogenesis of BOS are the multiple risk factors that have been detailed via epidemiologic investigations. Both alloimmune and alloimmuneindependent factors appear to play principle roles in the development of BOS. (Knoop and Estenne 2006) Primary graft dysfunction, along with gastroesophageal reflux (GER), and infection are all nonalloimmune factors that are associated with occurrence of BOS. (Estenne and Hertz 2002) CMV infection resulting in disease has been reported to enhance the relative risk of developing BOS, although there are conflicting reports regarding this. (Belperio et al. 2009) Alloimmune factors closely associated with BOS are recurrent, or persistent AR, and HLA mismatching. (Palmer et al. 2002)

\subsubsection{Treatment of bronchiolitis obliterans syndrome}

Currently there are no demonstrated effective treatments for BOS. Most present strategies rely on augmenting immunosuppression with the use of corticosteroids, cyclosporine, methotrexate, etc. (Date et al. 1998; Dusmet et al. 1996; Iacono et al. 1996) These, however have been met with little success. The majority of existing treatment methods rely on unproven, anecdotal evidence with few multi-center, randomized, controlled trials.

\subsubsection{Current research and future directions in bronchiolitis obliterans syndrome}

Our previously published hypothesis regarding the onset of BOS is that there is some initial insult (infection by CMV or other pathogens, inflammatory damage due to recurrent AR, etc.) that awakens the adaptive immune system to over-ride the potent cocktail of immunosuppressive drugs present. The adaptive immune (Type 1, and Type $2 \mathrm{~T}$ cells) further damages the transplanted organ by responding to the foreign epitopes innately present in the donor lung. This repeated damage induces a persistent release of proinflammatory cytokines that recruit neutrophils into the interstitium and airways where they remain and participate in a fibroproliferative and proteolytically destructive process. (Hardison et al. 2009)

\subsubsection{Potential Biomarkers in Bronchiolitis Obliterans Syndrome}

We, along with others, have reported on the activation of neutrophils by glutamate-leucinearginine positive (ELR+) CXC chemokines such as IL-8. (Xu et al. 2011; Chakrabarti and Patel 2005) Upon activation, neutrophils degranulate which releases potent proteases such as matrix metalloproteinase-8, -9, and prolyl endopeptidase. (Xu 2011, O'Reilly 2010) It has been well established that collagen fragments are chemotactic to neutrophils, and in 1995, Pfister et al. were able to determine the sequence, proline-glycine-proline (Pro-Gly-Pro, PGP) confers chemotactic potential to collagen breakdown products. (Pfister et al. 1995) In a 2006 paper, our group demonstrated the mechanism by which PGP is able to attract neutrophils into tissue. PGP shares significant sequence and structural homology with almost all ELR+CXC chemokines, which act via CXC receptors 1 and 2 in human (CXCR1, CXCR2). We reported that PGP competes with the CXCR ligand, IL-8, for binding, causes chemotaxis in CXCR transfected cells and elicits a similar oxidative burst to IL-8 stimulation. (Weathington et al. 2006) Recently we have also published the step-wise manner in which it is produced. (Gaggar et al. 2008)

MMP-8 and -9 are capable of initially digesting collagen but are incapable of performing the final cleavage to PGP and a second step is necessary for the matrikine's production. Our lab demonstrated that the serine protease prolyl endopeptidase (PE) performs the final 
proteolysis. (Gaggar et al. 2008) PE cleaves after a proline in a peptide of $\sim 100$ amino acids or less.

We have reported the potential for PGP as a biomarker of disease in multiple chronic inflammatory lung diseases such as cystic fibrosis (CF), chronic obstructive pulmonary disease (COPD), and most relevant to this manuscript, BOS. (Gaggar et al. 2007; O'Reilly et al. 2009; Hardison et al. 2009) In matched BAL samples of patients obtained three months prior to, and concurrent with diagnosis of BOS, we described a temporal shift in the chemokine/matrikine profile. MMP-8, -9 and PE activities were increased in the samples collected at diagnosis of BOS compared to a transplant control population, and matched samples collected prior to confirmation of disease. By employing a previously published mass spectrometry technique, we detected measureable amounts of PGP in both pre- and post-diagnosis of BOS, however, there was a dramatic and significant increase in the levels observed in BAL fluid collected at the time of diagnosis. Through the use of neutralizing antibodies to IL-8 and PGP, first individually and then in concert, we demonstrated a shift from the relative importance of the classical PMN chemoattractant, IL-8, to the more novel molecule, PGP, upon diagnosis of BOS.

Clearly PGP is not the only molecule with the potential to serve as a novel biomarker for BOS diagnosis. There is a litany of research underway on a wide variety of proteins and cell types that may potentially one day play a role in the more precise classification of this condition. Endothelin-1, mesenchymal stromal cells, and serum KL-6 (a glycoprotein) have all been published as possible markers of disease progression. (Salama et al. 2011; Badri et al. 2011; Haberman et al. 2010)

\subsubsection{Current Research in Bronchiolitis Obliterans Syndrome}

Perhaps the most exciting development in the quest for reliable preventative therapy for BOS has been the recent establishment of reproducible rodent models of BOS which closely mimic human disease. The most recent model described by Jungraithmayr, et al., utilizing single lung transplantation, is a vast improvement over the traditional tracheal transplant which had the obvious limitation of leaving the native lung in the rodent. (Jungraithmayr et al. 2010) The Swiss group reports that a T cell response and cytokine presence, similar to that of humans with BOS, was observed. Another group, from the University of Pittsburgh, has developed a human-mouse chimeric model of BOS in which the allograft and immune effector cells are of human origin. (Xue et al. 2011) They state that the formation of chimeric allogenic $\mathrm{T}$ cells, and the resulting infiltration into small human airways is definitive in delineating the role $\mathrm{T}$ cells play in the development of BOS.

\subsubsection{Future Therapeutics for Bronchiolitis Obliterans Syndrome}

This is, in part, a continuation of the previous section due to the experimental nature of some of the procedures/drugs described herein. As was previously discussed, there is an association of GER and BOS incidence. A study out of Duke University describes improved pulmonary function in patients who underwent proactive treatment for GER. Surgical fundoplication was performed to reduce the possibility of bile aspiration and potential damage to the airway. (Davis et al. 2003) Additionally, a retrospective study of transplant recipients with BOS identified a possible advantage of treatment with Azithromycin (Az), though the mechanism of action remains unclear. (Jain et al. 2010) Patients with a higher initial neutrophil burden responded better to the treatment and had better outcomes. What is most interesting is the fact that azithromycin is a macrolide antibiotic, a class known to be 
inhibitors of matrix metalloproteinases. It is possible that $\mathrm{Az}$ is preventing the generation of PGP and thus relieving some of the neutrophil burden associated with BOS.

A recent publication by our group in Science detailed a bi-functional enzyme, Leukotriene A4 Hydrolase (LTA4H), which serves to degrade PGP endogenously. This enzyme is present in both neutrophils and airway epithelium and is elevated in a mouse model of pulmonary infection and inflammation. (Snelgrove et al. 2010) Modulation of the activity of this important enzyme may provide a welcome opportunity to utilize patients' own biology to help resolve some of the destructive chronic neutrophilic inflammation seen in BOS. We have also described two specific inhibitors of PGP, arginine-threonine-arginine (RTR), and an all " $\mathrm{D}$ " isomer of PGP (DD-PGP) that are potent in preventing the mechanism of action of PGP in vitro and in vivo. (Jackson et al. 2011; van Houwelingen et al. 2008)

\section{Conclusion}

Even though long-term survival of lung transplant recipients has improved over time, the overall mortality rate in lung transplantation remains significantly higher than any other whole organ transplant population. The relatively recent advent of a more appropriate organ allocation system, along with improved ability to preserve donor organs has increased the pool of available organs to all-time highs. Even so, the number of actual lungs harvested each year compared to the estimated viable donor lungs is a small fraction of what is possible. With continued advancement in animal models, and description of biomarkers of the various complications associated with transplantation, there has been marked, if gradual, improvements in the therapeutic armament clinicians have at their disposal. It may yet be that lung transplantation one day be viewed as an early intervention in progressive irreversible pulmonary conditions such as idiopathic pulmonary fibrosis and confer a permanent, rejuvenative improvement in the lifespan and quality of life of such patients.

\section{References}

Aboyoun, C. L., M. Tamm, P. N. Chhajed, P. Hopkins, M. A. Malouf, S. Rainer, and A. R. Glanville. 2001. Diagnostic value of follow-up transbronchial lung biopsy after lung rejection. Am J Respir Crit Care Med 164 (3):460-3.

Aguilar-Guisado, M., J. Givalda, P. Ussetti, A. Ramos, P. Morales, M. Blanes, G. Bou, J. de la Torre-Cisneros, A. Roman, J. M. Borro, R. Lama, and J. M. Cisneros. 2007. Pneumonia after lung transplantation in the RESITRA Cohort: a multicenter prospective study. Am J Transplant 7 (8):1989-96.

Ahmad, S., O. A. Shlobin, and S. D. Nathan. 2011. Pulmonary complications of lung transplantation. Chest 139 (2):402-11.

Arcasoy, S. M. 2004. Medical complications and management of lung transplant recipients. Respir Care Clin N Am 10 (4):505-29.

Arcasoy, S. M., and R. M. Kotloff. 1999. Lung transplantation. N Engl J Med 340 (14):1081-91.

Ardehali, A., H. Laks, M. Levine, R. Shpiner, D. Ross, L. D. Watson, O. Shvartz, S. Sangwan, and P. F. Waters. 2001. A prospective trial of inhaled nitric oxide in clinical lung transplantation. Transplantation 72 (1):112-5. 
Avlonitis, V. S., C. H. Wigfield, J. A. Kirby, and J. H. Dark. 2005. The hemodynamic mechanisms of lung injury and systemic inflammatory response following brain death in the transplant donor. Am J Transplant 5 (4 Pt 1):684-93.

Badri, L., S. Murray, L. X. Liu, N. M. Walker, A. Flint, A. Wadhwa, K. M. Chan, G. B. Toews, D. J. Pinsky, F. J. Martinez, and V. N. Lama. 2011. Mesenchymal stromal cells in bronchoalveolar lavage as predictors of bronchiolitis obliterans syndrome. Am J Respir Crit Care Med 183 (8):1062-70.

Bando, K., I. L. Paradis, S. Similo, H. Konishi, K. Komatsu, T. G. Zullo, S. A. Yousem, J. M. Close, A. Zeevi, R. J. Duquesnoy, and et al. 1995. Obliterative bronchiolitis after lung and heart-lung transplantation. An analysis of risk factors and management. J Thorac Cardiovasc Surg 110 (1):4-13; discussion 13-4.

Barr, M. L., S. M. Kawut, T. P. Whelan, R. Girgis, H. Bottcher, J. Sonett, W. Vigneswaran, D. M. Follette, and P. A. Corris. 2005. Report of the ISHLT Working Group on Primary Lung Graft Dysfunction part IV: recipient-related risk factors and markers. J Heart Lung Transplant 24 (10):1468-82.

Belperio, J. A., S. S. Weigt, M. C. Fishbein, and J. P. Lynch, 3rd. 2009. Chronic lung allograft rejection: mechanisms and therapy. Proc Am Thorac Soc 6 (1):108-21.

Billings, J. L., M. I. Hertz, K. Savik, and C. H. Wendt. 2002. Respiratory viruses and chronic rejection in lung transplant recipients. J Heart Lung Transplant 21 (5):559-66.

Bittner, H. B., M. J. Barten, C. Binner, S. Lehmann, J. Garbade, S. Hammerschmidt, H. Wirtz, and F. W. Mohr. 2010. Preoperative introduction and maintenance immunosuppression therapy of oral-only tacrolimus, mycophenolate mofetil and steroids reduce acute rejection episodes after lung transplantation. Eur $J$ Cardiothorac Surg 38 (3):268-76.

Boehler, A., and M. Estenne. 2003. Post-transplant bronchiolitis obliterans. Eur Respir J 22 (6):1007-18.

Botha, P., L. Archer, R. L. Anderson, J. Lordan, J. H. Dark, P. A. Corris, K. Gould, and A. J. Fisher. 2008. Pseudomonas aeruginosa colonization of the allograft after lung transplantation and the risk of bronchiolitis obliterans syndrome. Transplantation 85 (5):771-4.

Botha, P., A. J. Rostron, A. J. Fisher, and J. H. Dark. 2008. Current strategies in donor selection and management. Semin Thorac Cardiovasc Surg 20 (2):143-51.

Brugiere, O., G. Thabut, C. Suberbielle, M. Reynaud-Gaubert, P. Thomas, C. Pison, C. Saint Raymond, J. F. Mornex, M. Bertocchi, C. Dromer, J. F. Velly, M. Stern, B. Philippe, G. Dauriat, G. Biondi, Y. Castier, and M. Fournier. 2008. Relative impact of human leukocyte antigen mismatching and graft ischemic time after lung transplantation. J Heart Lung Transplant 27 (6):628-34.

Campos, S., M. Caramori, R. Teixeira, J. Afonso, Jr., R. Carraro, T. Strabelli, M. Samano, P. Pego-Fernandes, and F. Jatene. 2008. Bacterial and fungal pneumonias after lung transplantation. Transplant Proc 40 (3):822-4.

Carter, Y. M., A. E. Gelman, and D. Kreisel. 2008. Pathogenesis, management, and consequences of primary graft dysfunction. Semin Thorac Cardiovasc Surg 20 (2):16572.

Chakinala, M. M., J. Ritter, B. F. Gage, J. P. Lynch, A. Aloush, G. A. Patterson, and E. P. Trulock. 2004. Yield of surveillance bronchoscopy for acute rejection and 
lymphocytic bronchitis/bronchiolitis after lung transplantation. J Heart Lung Transplant 23 (12):1396-404.

Chakrabarti, S., and K. D. Patel. 2005. Regulation of matrix metalloproteinase-9 release from IL-8-stimulated human neutrophils. J Leukoc Biol 78 (1):279-88.

Chamberlain, D., J. Maurer, C. Chaparro, and L. Idolor. 1994. Evaluation of transbronchial lung biopsy specimens in the diagnosis of bronchiolitis obliterans after lung transplantation. J Heart Lung Transplant 13 (6):963-71.

Christie, J. D., M. Carby, R. Bag, P. Corris, M. Hertz, and D. Weill. 2005. Report of the ISHLT Working Group on Primary Lung Graft Dysfunction part II: definition. A consensus statement of the International Society for Heart and Lung Transplantation. J Heart Lung Transplant 24 (10):1454-9.

Christie, J. D., L. B. Edwards, P. Aurora, F. Dobbels, R. Kirk, A. O. Rahmel, J. Stehlik, D. O. Taylor, A. Y. Kucheryavaya, and M. I. Hertz. 2009. The Registry of the International Society for Heart and Lung Transplantation: Twenty-sixth Official Adult Lung and Heart-Lung Transplantation Report-2009. J Heart Lung Transplant 28 (10):1031-49.

Christie, J. D., L. B. Edwards, A. Y. Kucheryavaya, P. Aurora, F. Dobbels, R. Kirk, A. O. Rahmel, J. Stehlik, and M. I. Hertz. The Registry of the International Society for Heart and Lung Transplantation: twenty-seventh official adult lung and heart-lung transplant report--2010. J Heart Lung Transplant 29 (10):1104-18.

Christie, J. D., R. M. Kotloff, A. Pochettino, S. M. Arcasoy, B. R. Rosengard, J. R. Landis, and S. E. Kimmel. 2003. Clinical risk factors for primary graft failure following lung transplantation. Chest 124 (4):1232-41.

Christie, J. D., N. Robinson, L. B. Ware, M. Plotnick, J. De Andrade, V. Lama, A. Milstone, J. Orens, A. Weinacker, E. Demissie, S. Bellamy, and S. M. Kawut. 2007. Association of protein $C$ and type 1 plasminogen activator inhibitor with primary graft dysfunction. Am J Respir Crit Care Med 175 (1):69-74.

Christie, J. D., J. S. Sager, S. E. Kimmel, V. N. Ahya, C. Gaughan, N. P. Blumenthal, and R. M. Kotloff. 2005. Impact of primary graft failure on outcomes following lung transplantation. Chest 127 (1):161-5.

Christie, J. D., C. V. Shah, S. M. Kawut, N. Mangalmurti, D. J. Lederer, J. R. Sonett, V. N. Ahya, S. M. Palmer, K. Wille, V. Lama, P. D. Shah, A. Shah, A. Weinacker, C. S. Deutschman, B. A. Kohl, E. Demissie, S. Bellamy, and L. B. Ware. 2009. Plasma levels of receptor for advanced glycation end products, blood transfusion, and risk of primary graft dysfunction. Am J Respir Crit Care Med 180 (10):1010-5.

Colombat, M., Y. Castier, G. Leseche, P. Rufat, H. Mal, G. Thabut, M. Fournier, O. Groussard, C. Degott, and A. Couvelard. 2004. Early expression of adhesion molecules after lung transplantation: evidence for a role of aggregated P-selectinpositive platelets in human primary graft failure. J Heart Lung Transplant 23 (9):1087-92.

Cooper, D. K. 1969. Transplantation of the heart and both lungs. I. Historical review. Thorax 24 (4):383-90.

Cooper, J. D., F. G. Pearson, G. A. Patterson, T. R. Todd, R. J. Ginsberg, M. Goldberg, and W. A. DeMajo. 1987. Technique of successful lung transplantation in humans. J Thorac Cardiovasc Surg 93 (2):173-81. 
Corris, P. A., and J. D. Christie. 2008. Update in transplantation 2007. Am J Respir Crit Care Med 177 (10):1062-7.

Cypel, M., M. Sato, E. Yildirim, W. Karolak, F. Chen, J. Yeung, C. Boasquevisque, V. Leist, L. G. Singer, K. Yasufuku, M. Deperrot, T. K. Waddell, S. Keshavjee, and A. Pierre. 2009. Initial experience with lung donation after cardiocirculatory death in Canada. J Heart Lung Transplant 28 (8):753-8.

Date, H., J. P. Lynch, S. Sundaresan, G. A. Patterson, and E. P. Trulock. 1998. The impact of cytolytic therapy on bronchiolitis obliterans syndrome. J Heart Lung Transplant 17 (9):869-75.

Davis, R. D., Jr., C. L. Lau, S. Eubanks, R. H. Messier, D. Hadjiliadis, M. P. Steele, and S. M. Palmer. 2003. Improved lung allograft function after fundoplication in patients with gastroesophageal reflux disease undergoing lung transplantation. J Thorac Cardiovasc Surg 125 (3):533-42.

de Perrot, M., R. S. Bonser, J. Dark, R. F. Kelly, D. McGiffin, R. Menza, O. Pajaro, S. Schueler, and G. M. Verleden. 2005. Report of the ISHLT Working Group on Primary Lung Graft Dysfunction part III: donor-related risk factors and markers. J Heart Lung Transplant 24 (10):1460-7.

de Perrot, M., M. Liu, T. K. Waddell, and S. Keshavjee. 2003. Ischemia-reperfusion-induced lung injury. Am J Respir Crit Care Med 167 (4):490-511.

Demikhov, Vladimir. 1950. A new and simpler variant of heart-lung preparation of a warmblooded mammal. Bull Eksperimentalnoi Biologii i medicini 24:383-390.

Deuse, T., R. Sista, D. Weill, D. Tyan, F. Haddad, G. Dhillon, R. C. Robbins, and B. A. Reitz. 2010. Review of heart-lung transplantation at Stanford. Ann Thorac Surg 90 (1):32937.

Dhillon, G. S., J. Levitt, H. Mallidi, V. G. Valentine, M. R. Gupta, R. Sista, and D. Weill. 2009. Impact of hepatitis B core antibody positive donors in lung and heart-lung transplantation: an analysis of the United Network For Organ Sharing Database. Transplantation 88 (6):842-6.

Diamond, J. M., S. M. Kawut, D. J. Lederer, V. N. Ahya, B. Kohl, J. Sonett, S. M. Palmer, M. Crespo, K. Wille, V. N. Lama, P. D. Shah, J. Orens, S. Bhorade, A. Weinacker, E. Demissie, S. Bellamy, J. D. Christie, and L. B. Ware. 2011. Elevated plasma clara cell secretory protein concentration is associated with high-grade primary graft dysfunction. Am J Transplant 11 (3):561-7.

Dilling, D. F., and A. R. Glanville. 2011. Advances in lung transplantation: the year in review. J Heart Lung Transplant 30 (3):247-51.

Dusmet, M., J. Maurer, T. Winton, and S. Kesten. 1996. Methotrexate can halt the progression of bronchiolitis obliterans syndrome in lung transplant recipients. $J$ Heart Lung Transplant 15 (9):948-54.

Egan, T. M., S. Murray, R. T. Bustami, T. H. Shearon, K. P. McCullough, L. B. Edwards, M. A. Coke, E. R. Garrity, S. C. Sweet, D. A. Heiney, and F. L. Grover. 2006. Development of the new lung allocation system in the United States. Am J Transplant 6 (5 Pt 2):1212-27.

Eriksson, L. T., R. Roscher, R. Ingemansson, and S. Steen. 1999. Cardiovascular effects of induced hypothermia after lung transplantation. Ann Thorac Surg 67 (3):804-9. 
Eriksson, L. T., and S. Steen. 1998. Induced hypothermia in critical respiratory failure after lung transplantation. Ann Thorac Surg 65 (3):827-9.

Estenne, M., and M. I. Hertz. 2002. Bronchiolitis obliterans after human lung transplantation. Am J Respir Crit Care Med 166 (4):440-4.

Estenne, M., J. R. Maurer, A. Boehler, J. J. Egan, A. Frost, M. Hertz, G. B. Mallory, G. I. Snell, and S. Yousem. 2002. Bronchiolitis obliterans syndrome 2001: an update of the diagnostic criteria. J Heart Lung Transplant 21 (3):297-310.

Fisher, A. J., S. C. Donnelly, N. Hirani, M. D. Burdick, R. M. Strieter, J. H. Dark, and P. A. Corris. 1999. Enhanced pulmonary inflammation in organ donors following fatal non-traumatic brain injury. Lancet 353 (9162):1412-3.

Fisher, A. J., S. C. Donnelly, N. Hirani, C. Haslett, R. M. Strieter, J. H. Dark, and P. A. Corris. 2001. Elevated levels of interleukin-8 in donor lungs is associated with early graft failure after lung transplantation. Am J Respir Crit Care Med 163 (1):259-65.

Fishman, J. A., V. Emery, R. Freeman, M. Pascual, L. Rostaing, H. J. Schlitt, D. Sgarabotto, J. Torre-Cisneros, and M. E. Uknis. 2007. Cytomegalovirus in transplantation challenging the status quo. Clin Transplant 21 (2):149-58.

Flume, P. A., T. M. Egan, L. J. Paradowski, F. C. Detterbeck, J. T. Thompson, and J. R. Yankaskas. 1994. Infectious complications of lung transplantation. Impact of cystic fibrosis. Am J Respir Crit Care Med 149 (6):1601-7.

Freeman, R. B., Jr. 2009. The 'indirect' effects of cytomegalovirus infection. Am J Transplant 9 (11):2453-8.

Gaggar, A., P. L. Jackson, B. D. Noerager, P. J. O'Reilly, D. B. McQuaid, S. M. Rowe, J. P. Clancy, and J. E. Blalock. 2008. A novel proteolytic cascade generates an extracellular matrix-derived chemoattractant in chronic neutrophilic inflammation. J Immunol 180 (8):5662-9.

Gaggar, A., Y. Li, N. Weathington, M. Winkler, M. Kong, P. Jackson, J. E. Blalock, and J. P. Clancy. 2007. Matrix metalloprotease-9 dysregulation in lower airway secretions of cystic fibrosis patients. Am J Physiol Lung Cell Mol Physiol 293 (1):L96-L104.

Haberman, B., M. L. Doan, E. O. Smith, M. G. Schecter, G. B. Mallory, and O. Elidemir. 2010. Serum KL-6 level and the development of bronchiolitis obliterans syndrome in lung transplant recipients. Pediatr Transplant 14 (7):903-8.

Hachem, R. R. 2009. Lung allograft rejection: diagnosis and management. Curr Opin Organ Transplant 14 (5):477-82.

Handa, M., S. Fujimura, T. Kondo, T. Ichinose, Y. Shiraishi, and T. Nakada. 1989. A study of preservation solution for 48- and 96-hour simple hypothermic storage of canine lung transplants. Tohoku J Exp Med 159 (3):205-14.

Hardison, M. T., F. S. Galin, C. E. Calderon, U. V. Djekic, S. B. Parker, K. M. Wille, P. L. Jackson, R. A. Oster, K. R. Young, J. E. Blalock, and A. Gaggar. 2009. The presence of a matrix-derived neutrophil chemoattractant in bronchiolitis obliterans syndrome after lung transplantation. J Immunol 182 (7):4423-31.

Hardison, MT, Jackson, PL, Blalock, JE, Gaggar, A. 2009. Protease Release from Neutrophils in Inflammation: Impact on Innate Immunity Seen in Chronic Pulmonary Disease. In Handbook of Granulocytes: Classification, Toxic Materials Produced and Pathology, edited by R. H. a. S. Kohlund: Nova Science Publishers. 
Hardy, J. D., W. R. Webb, M. L. Dalton, Jr., and G. R. Walker, Jr. 1963. Lung Homotransplantation in Man. JAMA 186:1065-74.

Higuchi, T., T. Shiraishi, T. Shirakusa, S. Hirayama, H. Shibaguchi, M. Kuroki, M. Hiratuka, S. Yamamoto, and A. Iwasaki. 2005. Prevention of acute lung allograft rejection in rat by the janus kinase 3 inhibitor, tyrphostin AG490. J Heart Lung Transplant 24 (10):1557-64.

Hoffman, S. A., L. Wang, C. V. Shah, V. N. Ahya, A. Pochettino, K. Olthoff, A. Shaked, K. Wille, V. N. Lama, A. Milstone, L. B. Ware, J. Orens, A. Weinacker, E. Demissie, S. Bellamy, S. M. Kawut, W. W. Hancock, and J. D. Christie. 2009. Plasma cytokines and chemokines in primary graft dysfunction post-lung transplantation. Am J Transplant 9 (2):389-96.

Hopkins, P. M., C. L. Aboyoun, P. N. Chhajed, M. A. Malouf, M. L. Plit, S. P. Rainer, and A. R. Glanville. 2002. Prospective analysis of 1,235 transbronchial lung biopsies in lung transplant recipients. J Heart Lung Transplant 21 (10):1062-7.

Humar, A., Y. Lebranchu, F. Vincenti, E. A. Blumberg, J. D. Punch, A. P. Limaye, D. Abramowicz, A. G. Jardine, A. T. Voulgari, J. Ives, I. A. Hauser, and P. Peeters. 2010. The efficacy and safety of 200 days valganciclovir cytomegalovirus prophylaxis in high-risk kidney transplant recipients. Am J Transplant 10 (5):122837.

Iacono, A. T., R. J. Keenan, S. R. Duncan, G. C. Smaldone, J. H. Dauber, I. L. Paradis, N. P. Ohori, W. F. Grgurich, G. J. Burckart, A. Zeevi, E. Delgado, T. G. O'Riordan, M. M. Zendarsky, S. A. Yousem, and B. P. Griffith. 1996. Aerosolized cyclosporine in lung recipients with refractory chronic rejection. Am J Respir Crit Care Med $153(4 \mathrm{Pt}$ 1):1451-5.

Ison, M. G., and M. G. Michaels. 2009. RNA respiratory viral infections in solid organ transplant recipients. Am J Transplant 9 Suppl 4:S166-72.

Iwata, T., M. Chiyo, S. Yoshida, G. N. Smith, Jr., E. A. Mickler, R. Presson, Jr., A. J. Fisher, D. D. Brand, O. W. Cummings, and D. S. Wilkes. 2008. Lung transplant ischemia reperfusion injury: metalloprotease inhibition down-regulates exposure of type $\mathrm{V}$ collagen, growth-related oncogene-induced neutrophil chemotaxis, and tumor necrosis factor-alpha expression. Transplantation 85 (3):417-26.

Jackson, P. L., B. D. Noerager, M. J. Jablonsky, M. T. Hardison, B. D. Cox, J. C. Patterson, B. Dhanapal, J. E. Blalock, and D. D. Muccio. 2011. A CXCL8 receptor antagonist based on the structure of N-acetyl-proline-glycine-proline. Eur J Pharmacol. In Press.

Jain, R., R. R. Hachem, M. R. Morrell, E. P. Trulock, M. M. Chakinala, R. D. Yusen, H. J. Huang, T. Mohanakumar, G. A. Patterson, and M. J. Walter. 2010. Azithromycin is associated with increased survival in lung transplant recipients with bronchiolitis obliterans syndrome. J Heart Lung Transplant 29 (5):531-7.

Jaksch, P., B. Zweytick, H. Kerschner, A. M. Hoda, M. Keplinger, G. Lang, C. Aigner, and W. Klepetko. 2009. Cytomegalovirus prevention in high-risk lung transplant recipients: comparison of 3- vs 12-month valganciclovir therapy. J Heart Lung Transplant 28 (7):670-5.

Jung, F. J., L. Yang, I. De Meester, K. Augustyns, M. Cardell, S. Hillinger, P. Vogt, D. Lardinois, S. Scharpe, W. Weder, and S. Korom. 2006. CD26/dipeptidylpeptidase 
IV-targeted therapy of acute lung rejection in rats. J Heart Lung Transplant 25 (9):1109-16.

Jungraithmayr, W., P. Vogt, I. Inci, S. Hillinger, S. Arni, S. Korom, and W. Weder. 2010. A model of chronic lung allograft rejection in the rat. Eur Respir 35 (6):1354-63.

Kaneda, H., T. K. Waddell, M. de Perrot, X. H. Bai, C. Gutierrez, T. Arenovich, C. Chaparro, M. Liu, and S. Keshavjee. 2006. Pre-implantation multiple cytokine mRNA expression analysis of donor lung grafts predicts survival after lung transplantation in humans. Am J Transplant 6 (3):544-51.

Kawut, S. M., J. Okun, D. Shimbo, D. J. Lederer, J. De Andrade, V. Lama, A. Shah, A. Milstone, L. B. Ware, A. Weinacker, E. Demissie, and J. D. Christie. 2009. Soluble pselectin and the risk of primary graft dysfunction after lung transplantation. Chest 136 (1):237-44.

Keshavjee, S., R. D. Davis, M. R. Zamora, M. de Perrot, and G. A. Patterson. 2005. A randomized, placebo-controlled trial of complement inhibition in ischemiareperfusion injury after lung transplantation in human beings. J Thorac Cardiovasc Surg 129 (2):423-8.

Knoop, C., and M. Estenne. 2006. Acute and chronic rejection after lung transplantation. Semin Respir Crit Care Med 27 (5):521-33.

Korom, S., I. De Meester, T. H. Stadlbauer, A. Chandraker, M. Schaub, M. H. Sayegh, A. Belyaev, A. Haemers, S. Scharpe, and J. W. Kupiec-Weglinski. 1997. Inhibition of CD26/dipeptidyl peptidase IV activity in vivo prolongs cardiac allograft survival in rat recipients. Transplantation 63 (10):1495-500.

Kotloff, R. M., and G. Thabut. 2011. Lung transplantation. Am J Respir Crit Care Med 184 (2):159-71.

Kotton, C. N., D. Kumar, A. M. Caliendo, A. Asberg, S. Chou, D. R. Snydman, U. Allen, and A. Humar. 2010. International consensus guidelines on the management of cytomegalovirus in solid organ transplantation. Transplantation 89 (7):779-95.

Kramer, M. R., S. E. Marshall, V. A. Starnes, P. Gamberg, Z. Amitai, and J. Theodore. 1993. Infectious complications in heart-lung transplantation. Analysis of 200 episodes. Arch Intern Med 153 (17):2010-6.

Lande, J. D., J. Patil, N. Li, T. R. Berryman, R. A. King, and M. I. Hertz. 2007. Novel insights into lung transplant rejection by microarray analysis. Proc Am Thorac Soc 4 (1):44-51.

Lease, E. D., and D. W. Zaas. 2010. Complex bacterial infections pre- and posttransplant. Semin Respir Crit Care Med 31 (2):234-42.

Lee, J. C., and J. D. Christie. 2009. Primary graft dysfunction. Clin Chest Med 32 (2):279-93.

Lee, J., W. W. Yew, C. F. Wong, P. C. Wong, and C. S. Chiu. 2003. Multidrug-resistant tuberculosis in a lung transplant recipient. J Heart Lung Transplant 22 (10):1168-73.

Madsen, C. B., A. Norgaard, M. Iversen, and L. P. Ryder. 2010. Elevated mRNA levels of CTLA-4, FoxP3, and granzyme B in BAL, but not in blood, during acute rejection of lung allografts. Transpl Immunol 24 (1):26-32.

Mangi, A. A., D. P. Mason, E. R. Nowicki, L. H. Batizy, S. C. Murthy, D. J. Pidwell, R. K. Avery, K. R. McCurry, G. B. Pettersson, and E. H. Blackstone. 2011. Predictors of acute rejection after lung transplantation. Ann Thorac Surg 91 (6):1754-62.

Maurer, J. R., A. E. Frost, M. Estenne, T. Higenbottam, and A. R. Glanville. 1998. International guidelines for the selection of lung transplant candidates. The 
International Society for Heart and Lung Transplantation, the American Thoracic Society, the American Society of Transplant Physicians, the European Respiratory Society. Transplantation 66 (7):951-6.

Meade, M. O., J. T. Granton, A. Matte-Martyn, K. McRae, B. Weaver, P. Cripps, and S. H. Keshavjee. 2003. A randomized trial of inhaled nitric oxide to prevent ischemiareperfusion injury after lung transplantation. Am J Respir Crit Care Med 167 (11):1483-9.

Meyers, B. F., and G. A. Patterson. 2000. Current status of lung transplantation. Adv Surg 34:301-18.

Millet, B., T. W. Higenbottam, C. D. Flower, S. Stewart, and J. Wallwork. 1989. The radiographic appearances of infection and acute rejection of the lung after heartlung transplantation. Am Rev Respir Dis 140 (1):62-7.

Morrish, W. F., S. J. Herman, G. L. Weisbrod, and D. W. Chamberlain. 1991. Bronchiolitis obliterans after lung transplantation: findings at chest radiography and highresolution CT. The Toronto Lung Transplant Group. Radiology 179 (2):487-90.

Morton, J., and A. R. Glanville. 2009. Lung transplantation in patients with cystic fibrosis. Semin Respir Crit Care Med 30 (5):559-68.

Nash, E. F., A. Coonar, R. Kremer, E. Tullis, M. Hutcheon, L. G. Singer, S. Keshavjee, and C. Chaparro. 2010. Survival of Burkholderia cepacia sepsis following lung transplantation in recipients with cystic fibrosis. Transpl Infect Dis 12 (6):551-4.

Neofytos, D., J. A. Fishman, D. Horn, E. Anaissie, C. H. Chang, A. Olyaei, M. Pfaller, W. J. Steinbach, K. M. Webster, and K. A. Marr. 2010. Epidemiology and outcome of invasive fungal infections in solid organ transplant recipients. Transpl Infect Dis 12 (3):220-9.

Neurohr, C., P. Huppmann, B. Samweber, S. Leuschner, G. Zimmermann, H. Leuchte, R. Baumgartner, R. Hatz, L. Frey, P. Ueberfuhr, I. Bittmann, and J. Behr. 2009. Prognostic value of bronchoalveolar lavage neutrophilia in stable lung transplant recipients. J Heart Lung Transplant 28 (5):468-74.

O'Reilly, P., M. T. Hardison, P. L. Jackson, X. Xu, R. J. Snelgrove, A. Gaggar, F. S. Galin, and J. E. Blalock. 2010. Neutrophils contain prolyl endopeptidase and generate the chemotactic peptide, PGP, from collagen. J Neuroimmunology 217 (1-2):51-54.

O'Reilly, P., P. L. Jackson, B. Noerager, S. Parker, M. Dransfield, A. Gaggar, and J. E. Blalock. 2009. N-alpha-PGP and PGP, potential biomarkers and therapeutic targets for COPD. Respir Res 10:38.

Ojo, A. O., R. A. Wolfe, A. B. Leichtman, D. M. Dickinson, F. K. Port, and E. W. Young. 1999. A practical approach to evaluate the potential donor pool and trends in cadaveric kidney donation. Transplantation 67 (4):548-56.

Okada, Y., and T. Kondo. 2009. Preservation solution for lung transplantation. Gen Thorac Cardiovasc Surg 57 (12):635-9.

Okada, Y., A. M. Marchevsky, X. J. Zuo, J. A. Pass, R. M. Kass, J. M. Matloff, and S. C. Jordan. 1997. Accumulation of platelets in rat syngeneic lung transplants: a potential factor responsible for preservation-reperfusion injury. Transplantation 64 (6):801-6.

Orens, J. B., and E. R. Garrity, Jr. 2009. General overview of lung transplantation and review of organ allocation. Proc Am Thorac Soc 6 (1):13-9. 
Otulana, B. A., T. Higenbottam, L. Ferrari, J. Scott, G. Igboaka, and J. Wallwork. 1990. The use of home spirometry in detecting acute lung rejection and infection following heart-lung transplantation. Chest 97 (2):353-7.

Palmer, S. M., R. D. Davis, D. Hadjiliadis, M. I. Hertz, D. N. Howell, F. E. Ward, K. Savik, and N. L. Reinsmoen. 2002. Development of an antibody specific to major histocompatibility antigens detectable by flow cytometry after lung transplant is associated with bronchiolitis obliterans syndrome. Transplantation 74 (6):799-804.

Palmer, S. M., A. P. Limaye, M. Banks, D. Gallup, J. Chapman, E. C. Lawrence, J. Dunitz, A. Milstone, J. Reynolds, G. L. Yung, K. M. Chan, R. Aris, E. Garrity, V. Valentine, J. McCall, S. C. Chow, R. D. Davis, and R. Avery. 2010. Extended valganciclovir prophylaxis to prevent cytomegalovirus after lung transplantation: a randomized, controlled trial. Ann Intern Med 152 (12):761-9.

Petrucci, N., and W. Iacovelli. 2003. Ventilation with lower tidal volumes versus traditional tidal volumes in adults for acute lung injury and acute respiratory distress syndrome. Cochrane Database Syst Rev (3):CD003844.

Pfister, R. R., J. L. Haddox, C. I. Sommers, and K. W. Lam. 1995. Identification and synthesis of chemotactic tripeptides from alkali-degraded whole cornea. A study of $\mathrm{N}$-acetylproline-glycine-proline and N-methyl-proline-glycine-proline. Invest Ophthalmol Vis Sci 36 (7):1306-16.

Pratschke, J., M. J. Wilhelm, M. Kusaka, F. Beato, E. L. Milford, W. W. Hancock, and N. L. Tilney. 2000. Accelerated rejection of renal allografts from brain-dead donors. Ann Surg 232 (2):263-71.

Prekker, M. E., D. S. Nath, A. R. Walker, A. C. Johnson, M. I. Hertz, C. S. Herrington, D. M. Radosevich, and P. S. Dahlberg. 2006. Validation of the proposed International Society for Heart and Lung Transplantation grading system for primary graft dysfunction after lung transplantation. J Heart Lung Transplant 25 (4):371-8.

Salama, M., P. Jaksch, O. Andrukhova, S. Taghavi, W. Klepetko, and S. Aharinejad. 2011. Endothelin-1 is a useful biomarker for early detection of bronchiolitis obliterans in lung transplant recipients. J Thorac Cardiovasc Surg 140 (6):1422-7.

Shargall, Y., G. Guenther, V. N. Ahya, A. Ardehali, A. Singhal, and S. Keshavjee. 2005. Report of the ISHLT Working Group on Primary Lung Graft Dysfunction part VI: treatment. J Heart Lung Transplant 24 (10):1489-500.

Shohami, E., M. Novikov, R. Bass, A. Yamin, and R. Gallily. 1994. Closed head injury triggers early production of TNF alpha and IL-6 by brain tissue. J Cereb Blood Flow Metab 14 (4):615-9.

Sims, K. D., and E. A. Blumberg. 2011. Common infections in the lung transplant recipient. Clin Chest Med 32 (2):327-41.

Singh, N. 2003. Fungal infections in the recipients of solid organ transplantation. Infect Dis Clin North Am 17 (1):113-34, viii.

Skrabal, C. A., L. O. Thompson, E. V. Potapov, R. E. Southard, D. L. Joyce, K. A. Youker, G. P. Noon, and M. Loebe. 2005. Organ-specific regulation of pro-inflammatory molecules in heart, lung, and kidney following brain death. J Surg Res 123 (1):11825. 
Snydman, D. R., A. P. Limaye, L. Potena, and M. R. Zamora. 2011. Update and review: stateof-the-art management of cytomegalovirus infection and disease following thoracic organ transplantation. Transplant Proc 43 (3 Suppl):S1-S17.

Spital, A. 2005. Conscription of cadaveric organs for transplantation: a stimulating idea whose time has not yet come. Camb Q Healthc Ethics 14 (1):107-12.

Stewart, S., M. C. Fishbein, G. I. Snell, G. J. Berry, A. Boehler, M. M. Burke, A. Glanville, F. K. Gould, C. Magro, C. C. Marboe, K. D. McNeil, E. F. Reed, N. L. Reinsmoen, J. P. Scott, S. M. Studer, H. D. Tazelaar, J. L. Wallwork, G. Westall, M. R. Zamora, A. Zeevi, and S. A. Yousem. 2007. Revision of the 1996 working formulation for the standardization of nomenclature in the diagnosis of lung rejection. J Heart Lung Transplant 26 (12):1229-42.

Struber, M., J. M. Hohlfeld, T. Kofidis, G. Warnecke, J. Niedermeyer, S. P. Sommer, and A. Haverich. 2002. Surfactant function in lung transplantation after 24 hours of ischemia: advantage of retrograde flush perfusion for preservation. J Thorac Cardiovasc Surg 123 (1):98-103.

Tasoulis, M. K., O. Livaditi, M. Stamatakos, C. Stefanaki, P. Paneris, P. Prigouris, A. Flevari, N. Goutas, D. Vlachodimitropoulos, V. Villiotou, and E. E. Douzinas. 2009. High concentrations of reactive oxygen species in the BAL fluid are correlated with lung injury in rabbits after hemorrhagic shock and resuscitation. Tohoku J Exp Med 219 (3):193-9.

Trulock, E. P., J. D. Christie, L. B. Edwards, M. M. Boucek, P. Aurora, D. O. Taylor, F. Dobbels, A. O. Rahmel, B. M. Keck, and M. I. Hertz. 2007. Registry of the International Society for Heart and Lung Transplantation: twenty-fourth official adult lung and heart-lung transplantation report-2007. J Heart Lung Transplant 26 (8):782-95.

Valentine, V. G., R. W. Bonvillain, M. R. Gupta, G. A. Lombard, S. G. LaPlace, G. S. Dhillon, and G. Wang. 2008. Infections in lung allograft recipients: ganciclovir era. J Heart Lung Transplant 27 (5):528-35.

van Houwelingen, A. H., N. M. Weathington, V. Verweij, J. E. Blalock, F. P. Nijkamp, and G. Folkerts. 2008. Induction of lung emphysema is prevented by L-arginine-threoninearginine. FASEB J 22 (9):3403-8.

Vanaudenaerde, B. M., W. A. Wuyts, N. Geudens, T. S. Nawrot, R. Vos, L. J. Dupont, D. E. Van Raemdonck, and G. M. Verleden. 2008. Broncho-alveolar lavage fluid recovery correlates with airway neutrophilia in lung transplant patients. Respir Med 102 (3):339-47.

Vos, R., B. M. Vanaudenaerde, N. Geudens, L. J. Dupont, D. E. Van Raemdonck, and G. M. Verleden. 2008. Pseudomonal airway colonisation: risk factor for bronchiolitis obliterans syndrome after lung transplantation? Eur Respir J 31 (5):1037-45.

Weathington, N. M., A. H. van Houwelingen, B. D. Noerager, P. L. Jackson, A. D. Kraneveld, F. S. Galin, G. Folkerts, F. P. Nijkamp, and J. E. Blalock. 2006. A novel peptide CXCR ligand derived from extracellular matrix degradation during airway inflammation. Nat Med 12 (3):317-23.

Whitson, B. A., D. S. Nath, A. C. Johnson, A. R. Walker, M. E. Prekker, D. M. Radosevich, C. S. Herrington, and P. S. Dahlberg. 2006. Risk factors for primary graft dysfunction after lung transplantation. J Thorac Cardiovasc Surg 131 (1):73-80. 
Xu, X., P. L. Jackson, S. Tanner, M. T. Hardison, M. Abdul Roda, J. E. Blalock, and A. Gaggar. 2011. A self-propagating matrix metalloprotease-9 (MMP-9) dependent cycle of chronic neutrophilic inflammation. PLoS One 6 (1):e15781.

Xue, J., X. Zhu, M. P. George, M. M. Myerburg, M. W. Stoner, J. W. Pilewski, and S. R. Duncan. 2011. A human-mouse chimeric model of obliterative bronchiolitis after lung transplantation. Am J Pathol 179 (2):745-53.

Yousem, S. A., T. Martin, I. L. Paradis, R. Keenan, and B. P. Griffith. 1994. Can immunohistological analysis of transbronchial biopsy specimens predict responder status in early acute rejection of lung allografts? Hum Pathol 25 (5):525-9.

Zamora, M. R., R. D. Davis, and C. Leonard. 2005. Management of cytomegalovirus infection in lung transplant recipients: evidence-based recommendations. Transplantation 80 (2):157-63.

Zamora, M. R., M. R. Nicolls, T. N. Hodges, J. Marquesen, T. Astor, T. Grazia, and D. Weill. 2004. Following universal prophylaxis with intravenous ganciclovir and cytomegalovirus immune globulin, valganciclovir is safe and effective for prevention of CMV infection following lung transplantation. Am J Transplant 4 (10):1635-42. 


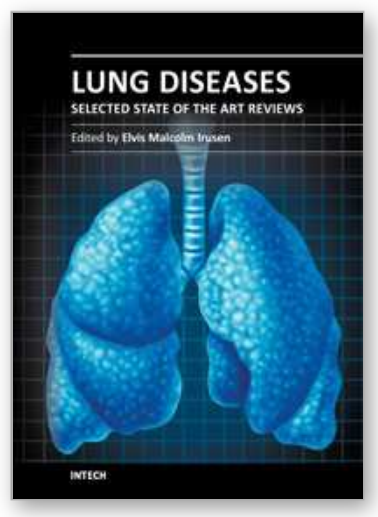

\section{Lung Diseases - Selected State of the Art Reviews}

Edited by Dr. Elvisegran Malcolm Irusen

ISBN 978-953-51-0180-2

Hard cover, 690 pages

Publisher InTech

Published online 02, March, 2012

Published in print edition March, 2012

The developments in molecular medicine are transforming respiratory medicine. Leading clinicians and scientists in the world have brought their knowledge and experience in their contributions to this book. Clinicians and researchers will learn about the most recent advances in a variety of lung diseases that will better enable them to understand respiratory disorders. This treatise presents state of the art essays on airways disease, neoplastic diseases, and pediatric respiratory conditions. Additionally, aspects of immune regulation, respiratory infections, acute lung injury/ARDS, pulmonary edema, functional evaluation in respiratory disorders, and a variety of other conditions are also discussed. The book will be invaluable to clinicians who keep up with the current concepts, improve their diagnostic skills, and understand potential new therapeutic applications in lung diseases, while scientists can contemplate a plethora of new research avenues for exploration.

\section{How to reference}

In order to correctly reference this scholarly work, feel free to copy and paste the following:

Matthew T. Hardison and J. Edwin Blalock (2012). Lung Transplantation: Advances and Roadblocks in Treatment, Lung Diseases - Selected State of the Art Reviews, Dr. Elvisegran Malcolm Irusen (Ed.), ISBN: 978-953-51-0180-2, InTech, Available from: http://www.intechopen.com/books/lung-diseases-selected-stateof-the-art-reviews/lung-transplantation-advances-and-roadblocks-in-treatment

\section{INTECH}

open science | open minds

\section{InTech Europe}

University Campus STeP Ri

Slavka Krautzeka 83/A

51000 Rijeka, Croatia

Phone: +385 (51) 770447

Fax: +385 (51) 686166

www.intechopen.com

\section{InTech China}

Unit 405, Office Block, Hotel Equatorial Shanghai

No.65, Yan An Road (West), Shanghai, 200040, China

中国上海市延安西路65号上海国际贵都大饭店办公楼 405 单元

Phone: +86-21-62489820

Fax: $+86-21-62489821$ 
(C) 2012 The Author(s). Licensee IntechOpen. This is an open access article distributed under the terms of the Creative Commons Attribution 3.0 License, which permits unrestricted use, distribution, and reproduction in any medium, provided the original work is properly cited. 